\title{
Tecnologias digitais, letramentos e gêneros discursivos nas diferentes áreas da BNCC: reflexos nos anos finais do ensino fundamental e na formação de professores
}

\author{
Ângela Francine Fuza' \\ Flávia Danielle Sordi Silva Miranda" (ID
}

RESUMO

Neste artigo analisamos os anos finais do ensino fundamental na Base Nacional Comum Curricular nas diferentes áreas de conhecimento, refletindo sobre seus impactos na escola básica e na formação de professores. O trabalho é documental, situado na Linguística Aplicada, e dialoga com os Novos Estudos do Letramento. Os dados foram gerados da análise do documento, orientada pela questão do digital proposta pela normativa. Os caminhos que orientaram as discussões: o entendimento sobre a concepção de letramento, de tecnologias digitais e a identificação de gêneros discursivos sugeridos nos componentes. Os resultados apontam práticas de letramento ideológico embasando ações sugeridas para as áreas, ainda que haja variação sobre como e o que seja usar tecnologias digitais em situações de ensino e no trabalho com gêneros. Acreditamos que os reflexos da Base Nacional Comum Curricular sobre as práticas escolares e a formação docente ainda precisam ser avaliados, a despeito dos benefícios sinalizados por ela.

PALAVRAS-CHAVE

Base Nacional Comum Curricular; ensino fundamental; formação de professores; tecnologias digitais.

'Universidade Federal do Tocantins, Porto Nacional, TO, Brasil.

"Universidade Federal de Uberlândia, Uberlândia, MG, Brasil. 


\title{
DIGITAL TECHNOLOGIES, LETTERINGS AND DISCURSIVE GENRES IN DIFFERENT AREAS OF THE BNCC: REFLEXES IN THE FINAL YEARS OF ELEMENTARY AND MIDDLE SCHOOLS AND IN THE FORMATION OF TEACHERS
}

\begin{abstract}
In this article, we analyze the final years of elementary and middle schools, in the National Common Curricular Base, in different knowledge areas, reflecting on their impacts on basic school and on the formation of teachers. It is a documental paper, situated in the Applied Linguistics and it dialogues with the New Studies of Literacy. The data were generated from the analysis of the document, guided by the digital matter proposed by the normative. The paths that guided the talks: the understanding of the conception of literacy, digital technologies and the identification of discursive genre suggested in the components. The results point to ideological literacy practices based upon actions suggested for the areas, even if there is a variation about how and what it is to use digital technologies in teaching situations and in the work with the discursive genre. We believe that the reflexes of National Common Curricular Base on school practices and the formation of teachers still need to be assessed, despite the benefits signaled by it.
\end{abstract}

KEYWORDS

National Common Curricular Base; elementary teaching; formation of teachers; digital technologies.

\section{TECNOLOGÍAS DIGITALES, LITERACIDADES Y GÉNEROS DEL DISCURSO EN LAS DIFERENTES ÁREAS DE LA BNCC: REFLEJOS EN LOS AÑOS FINALES DE LA ENSEÑANZA FUNDAMENTAL Y EN LA FORMACIÓN DE PROFESORES}

\section{RESUMEN}

En este artículo analizamos los últimos años de la escuela primaria, en la Base de Currículo Nacional Común, en las diferentes áreas de conocimiento, reflexionando sobre sus impactos en la escuela primaria y en la formación de maestros. El trabajo es documental, ubicado en Lingüística Aplicada, y diálogos con los Nuevos Estudios de Alfabetización. Los datos se generaron a partir del análisis de documentos, guiados por el problema digital, propuesto por la normativa. Los caminos que guiaron las discusiones: comprensión sobre la concepción dela alfabetización, de tecnologías digitales y la identificación de géneros discursivos sugeridos en los componentes. Los resultados apuntan a prácticas de alfabetización ideológica que respaldan las acciones sugeridas para las áreas, a pesar de que existe una variación sobre cómo y qué usar las tecnologías digitales en situaciones de enseñanza y en el trabajo con géneros. Creemos que las reflexiones de Base de Currículo Nacional Común sobre las prácticas escolares y la formación docente aún deben evaluarse, a pesar de los beneficios señalados por este.

\section{PALABRAS CLAVE}

Base de Currículo Nacional Común; enseñanza fundamental; formación de profesores; tecnologías digitales. 


\section{INTRODUÇÃO}

A publicação do mais recente documento oficial para o ensino básico brasileiro, a Base Nacional Comum Curricular (BNCC), trouxe novos tópicos para um grande debate, remetendo a toda a história do ensino no país, caracterizando o momento atual como um marco, impactando currículos, escolas, livros didáticos, exames nacionais etc.

A BNCC não é currículo, mas sim um documento que determina os conhecimentos essenciais que os alunos da educação básica devem aprender, ano a ano. De acordo com o site Movimento pela Base Nacional Comum, ${ }^{1}$ "Os currículos das redes [...] devem conter conhecimentos e habilidades explicitados na BNCC [incluindo] metodologias e abordagens pedagógicas e [tratando] de especificidades educacionais e culturais locais, como educação inclusiva, quilombola, indígena”. Muitas foram as questões sobre os desafios de implementação da Base, desde a publicação de suas versões iniciais até sua homologação ${ }^{2}$ para o nível fundamental de ensino. Após a homologação da BNCC do ensino fundamental, foi a vez do ensino médio. ${ }^{3}$

Nos documentos, os conhecimentos encontram-se divididos por área de conhecimento, o que nos leva ao questionamento: Os currículos, então, devem ser organizados em conteúdos isolados em suas áreas? Vivemos em um contexto complexo, com diferentes perspectivas, em função das diversas áreas do saber. Logo, não seria viável pensar a organização curricular de modo que possibilitasse maior diálogo entre as áreas? Assim, uma reflexão crítica sobre a BNCC se faz fundamental justamente ao pensarmos na implementação das inovações curriculares nas escolas. As teorias sobre o currículo não são perspectivas acabadas, pois "convertem-se em marcos orientadores das concepções sobre a realidade que abarcam, e passam a ser formas, ainda que indiretas, de abordar os problemas práticos da educação" (Correia e Dias, 1998, p. 115).

Diante desse cenário, é necessário abordarmos as implicações da BNCC. Notamos a proliferação de artigos sobre o assunto sob diversos enfoques (Marsiglia et al., 2017; Orrú, 2018; Rocha e Pereira, 2016), muitos com críticas (Geraldi, 2015; Saviani, 2016; Szundy, 2017), além de materiais oferecidos para professores e gestores e planejamentos curriculares. ${ }^{4}$ Ao pensar em contribuições para endossar o entendimento sobre esse momento divisor de águas, apresentamos este artigo a partir de nossa localização como professoras, formadoras de professores e pesquisadoras na área de ensino, no âmbito da Linguística Aplicada.

Destarte, compreendemos que a BNCC tem efeito cascata em vários níveis, entre os quais iremos tratar, no artigo, dos reflexos no ensino fundamental II, doravante

1 Disponível em: movimentopelabase.org.br. Acesso em: 15 jan. 2020.

2 Disponível em: http://movimentopelabase.org.br/acontece/bncc-homologada/. Acesso em: 15 jan. 2020.

3 Disponível em: http://movimentopelabase.org.br/acontece/ensino-medio-bncc-e-homologada/. Acesso em: 15 jan. 2020.

4 Disponível em: http://basenacionalcomum.mec.gov.br/. Acesso em: 30 dez. 2018. 
EFII, e na formação de seus professores. Ambos estarão ligados, em nosso trabalho, pelo eixo da transversalidade das tecnologias digitais, trazida pelo próprio documento.

O objetivo deste texto é o de analisar concepções da BNCC sobre letramentos, tecnologias digitais e gêneros discursivos nas diferentes áreas do documento (Linguagens, Matemática, Ciências da Natureza, Ciências Humanas e Ensino Religioso), realizando uma reflexão interdisciplinar, haja vista que o trabalho com a língua(gem) deve ser pensado por todos os componentes curriculares na escola, e não somente pelo professor de português (Geraldi, 2015).

Decorrente desse objetivo geral, especificamente, buscamos:

- verificar o entendimento do digital nas diferentes áreas do conhecimento na BNCC;

- refletir sobre implicações desse tratamento do digital no contexto escolar, manifestado no trabalho com gêneros discursivos;

- ponderar sobre os reflexos desse documento para a formação docente.

O artigo inicia-se com uma fundamentação teórica, que articula Linguística Aplicada e formação de professores (Kleiman, 1995) com a questão dos documentos parametrizadores (Geraldi, 2015; Rojo, 2000), pelo eixo das tecnologias digitais. $\mathrm{Na}$ sequência, explicitamos nossa orientação metodológica de pesquisa documental (Cellard, 2008; Lüdke e André, 1986) e oferecemos, na seção seguinte, análises de dados com nossos principais resultados. Finalmente, relacionamo-nos com os efeitos da BNCC para formação de professores nas considerações finais.

\section{FUNDAMENTAÇÃO TEÓRICA}

\section{TECNOLOGIAS DIGITAIS NA FORMAÇÃO DOCENTE}

Em publicação no início do século XXI, Buzato (2006) refletia sobre transformações sociais ocasionadas por tecnologias digitais para o trabalho docente. Afirmava o autor:

o que torna a formação do professor um desafio fantástico não é a ideia ingênua de que podemos/devemos recomeçar do zero, mas justamente a necessidade de integrar o novo com o que já temos/sabemos, a partir do que já temos/ sabemos, transformando esse conjunto de práticas, habilidades e significados. (Buzato, 2006, s/p.)

Tal "desafio" continuou a instigar pesquisas sobre formação de professores, em articulação com tecnologias digitais, entendendo-se que estas ressignificam a formação docente. Rojo (2017, p. 12) também trata do assunto, ao indicar que "Há, pois, diversas maneiras de as tecnologias da informação e da comunicação (TDIC) se relacionarem com o currículo e a pedagogia escolar [...]. No entanto, para poder fazê-lo, é preciso que o professor seja formado para isso". Essa visão dialoga diretamente com a Agenda ONU 2030 e com a BNCC: 
Até 2030, [a meta é] substancialmente aumentar o contingente de professores qualificados, inclusive por meio da cooperação internacional para a formação de professores [...]. (ONU, 2015 - Agenda ONU 2030, meta 4.c, grifos nossos)

A primeira tarefa de responsabilidade direta da União será a revisão da formação inicial e continuada dos professores para alinhá-las à BNCC. A ação nacional será crucial nessa iniciativa, já que se trata da esfera que responde pela regulação do ensino superior, nível no qual se prepara grande parte desses profissionais [...] essa é uma ação fundamental para a implementação eficaz da BNCC. (Brasil, 2017, p. 21, grifos nossos)

Os documentos tratam tanto da formação inicial quanto da continuada, fato que revela a $\mathrm{BNCC}$ como articulada com um cenário internacional e como espaço de elos entre o ensino básico e o superior, já que os professores precisariam de formação para alinhar suas ações. Rocha e Pereira (2016, p. 223), ao fazerem um levantamento sobre a publicação científica no campo da Educação em torno da BNCC, entre 2010 e 2015, advertem que "o debate sobre a BNCC está intimamente relacionado às questões de poder, formação docente e identidade”. Isso porque esse documento normativo se propõe a englobar a formação do aluno e do professor como sujeitos atuantes em seus contextos. A existência da BNCC não é garantia de que seus pressupostos serão realmente efetivados na escola, pois, além dela, é preciso que haja o professor, "um/a protagonista central para a manutenção e/ou transformação de currículos [Logo,] o lançamento de quaisquer diretrizes curriculares acaba por trazer posicionamentos acerca da formação de professores/as para o cerne das discussões" (Szundy, 2017, p. 85).

\section{TECNOLOGIAS DIGITAIS NOS DOCUMENTOS OFICIAIS}

Ao observar os documentos oficiais para a educação básica anteriores à BNCC, verificamos que a tentativa de articulação entre tecnologias digitais e práticas de ensino não foi uma inovação da normativa. Nos Parâmetros Curriculares Nacionais (PCN) do EFII, em sua "Introdução" geral, voltada para todas as áreas (Brasil, 1998), localizamos na quinta seção: "Tecnologias da Informação e Comunicação". Nela, tratava-se de tecnologias tradicionais e/ou analógicas, como a televisão e o videocassete, porém já figuravam considerações sobre "novas tecnologias da informação", o computador e a internet, e ainda sobre seus impactos para o professor, considerando que ele possuísse "conhecimento sobre as possibilidades do recurso tecnológico [...] isso não significa que o professor deva se tornar um especialista, mas que é necessário conhecer as potencialidades da ferramenta e saber utilizá-las" (Brasil, 1998, p. 154).

Se os PCN abordavam tecnologias, não enfatizavam, por sua vez, a forte relação entre elas e o meio digital, o que se denomina, nos últimos anos, de Tecnologias Digitais de Informação e Comunicação (TDIC). É na BNCC que a continuidade sobre práticas de ensino e tecnologias se dá, havendo uma intensificação 
da importância do digital. Uma busca no documento pelas palavras-chave "digital/ digitais", associadas ou não a "tecnologia/tecnologias”, revela o número de 248 ocorrências. Ainda que tal resultado indique preocupação em se aproximar das práticas de ensino contemporâneas (Rojo, 2012, 2013), como a própria BNCC justifica, alguns estudiosos assinalam a necessidade de avaliações críticas e compreensões mais aprofundadas sobre como a aliança entre tecnologias digitais e ensino poderá ocorrer com base no referido documento.

Segundo Saviani (2016, p. 82), "é preciso garantir não apenas o domínio técnico-operativo dessas tecnologias, mas a compreensão dos princípios científicos e dos processos que as tornaram possíveis", sob a pena de "não parece[r] exagerado considerar que estamos, de fato, [realizando] aquelas profecias dos textos de ficção científica que previram uma humanidade submetida ao jugo de suas próprias criaturas, sendo dirigidas por máquinas engrenadas em processos automáticos”. Essas considerações nos fazem cogitar as (im)possibilidades de trazer as tecnologias digitais para o ensino de todas as áreas, uma vez que a presença delas não garante melhorias na educação, podendo até mesmo acentuar problemas. Em contrapartida, a situação pode impactar nos modos como os professores as articulam em seu trabalho.

Em Szundy (2017), há reflexão sobre as concepções de linguagem que subjazem o documento e levam à percepção de uma consideração intrínseca do meio digital nas práticas de ensino. Ao realizar uma análise linguística, da área de Linguagens, a autora conclui que "a entextualização da concepção de que a linguagem verbal não é suficiente para compreender, transitar entre e transformar significados construídos na contemporaneidade"(Szundy, 2017, p. 89). Assim, outras linguagens, como aquelas difundidas nos meios digitais, são apresentadas como necessárias. Tão logo, é preciso um professor que saiba compreender, ensinar e construir conhecimento, valendo-se dessas diversas linguagens.

Geraldi (2015, p. 394) chegou a problematizar que "Produzir documentos oficiais, em lugar do convívio real com a escola para fazer uma mudança emergir de baixo para cima, é arvorar-se em profetas do que será o mundo futuro", ou seja, não temos necessariamente condições de saber como a proposição de trabalho com o digital se efetivará de fato, uma vez que sabemos das dificuldades de seu desenvolvimento no cenário educacional brasileiro.

Em síntese, o que as considerações desses e de outros autores nos convidam a pensar é em torno dos efeitos da intensa proposição de uso e produção de tecnologias digitais nos trabalhos de sala de aula. E mais, nos impactos para o trabalho e a formação docente, seja em qual área for. $\mathrm{Na}$ tentativa de contribuir com algumas reflexões para tais questões, apresentamos a pesquisa e nossas considerações analíticas.

\section{METODOLOGIA}

Este trabalho está situado no campo da Linguística Aplicada, em diálogo com os Novos Estudos do Letramento (Street, 2003), haja vista a centralização na linguagem e na relevância social (Valsechi e Kleiman, 2014), e configura-se como 
documental (Lüdke e André, 1986), tendo a BNCC como seu objeto. Trata-se de documento público não arquivado (Cellard, 2008), uma vez que está disponível para a realização de estudos.

A fim de compreender propostas com o digital nas diferentes áreas da $\mathrm{BNCC}$, o processo de análise de conteúdo do documento foi iniciado com a tomada de decisão sobre a unidade de registro (Lüdke e André,1986), ou seja, segmentos de conteúdo e trechos de texto, a respeito do termo "digital". Para a análise, realizamos alguns recortes, por conta de sua extensão. Optamos:

- pelo trabalho com o EFII, pois formamos professores para esse nível, e também por ser o momento em que os professores de todas as áreas são graduados em diferentes licenciaturas;

- pelo foco na abordagem do digital, tendo em vista a considerável presença do termo digital no documento;

- pelo trabalho com a leitura e a escrita (concepção de letramento), que revelam valores para os grupos (Kleiman, 1995).

Os dados foram coletados a partir da leitura da "Apresentação Geral" e da "Introdução" de cada área do conhecimento. Depois, cada área foi lida observando a questão do digital, dentro da seguinte configuração (Figura 1):

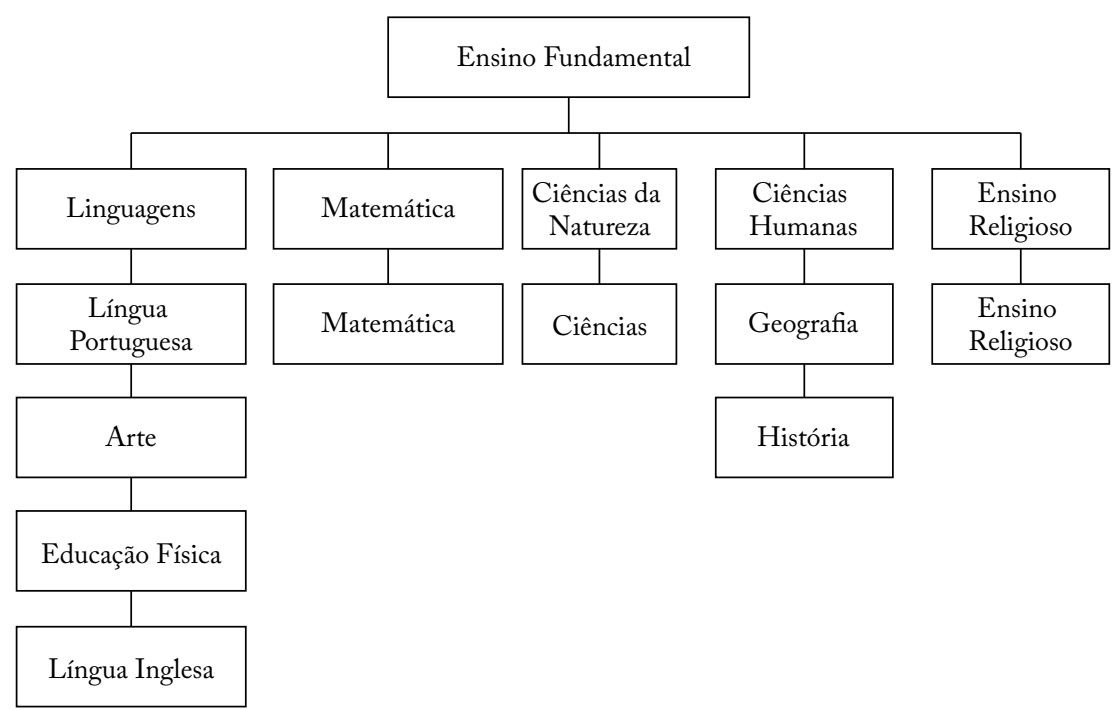

Fonte: Baseado em: http://basenacionalcomum.mec.gov.br/materiais-de-apoio. Elaboração das autoras.

Figura 1 -Áreas e componentes curriculares da Base Nacional Comum Curricular.

Alguns caminhos analíticos foram desenvolvidos para orientar as discussões. Houve a releitura dos textos das cinco áreas de conhecimento (Linguagens, Matemática, Ciências da Natureza, Ciências Humanas e Ensino Religioso), dos seus respectivos componentes e os dados foram gerados 
e analisados pensando-se no entendimento sobre a concepção de letramento apresentada por cada área do conhecimento; no entendimento sobre o digital no documento; nos gêneros discursivos sugeridos/propostos em associação ao digital para trabalho nas áreas. Optamos por esses caminhos analíticos, pois o próprio documento possibilita discussões sobre letramento, digital e gêneros discursivos, empregados nas práticas de linguagens.

\section{ANÁLISE DOS DADOS}

\section{CONCEPÇÕES DE LETRAMENTO NAS DIFERENTES ÁREAS}

Os estudos, principalmente de Street (1984), Kleiman (1995) e Soares (2006), impulsionaram discussões brasileiras a respeito do ensino da leitura e escrita, possibilitando novos modos de compreendê-las. As áreas de conhecimento, ao empregar o termo dentro de suas especificidades, têm optado por atribuir-lhe adjetivos. Na BNCC, a área de Ciências emprega "letramento científico"; a Matemática, "letramento matemático", e as Linguagens, "Multiletramentos". Embora se acredite que, por meio da adjetivação, estejam singularizando as áreas, o entendimento de letramento não está em sua adjetivação (Kleiman e De Grande, 2015), o que também defendemos. Entendemos letramento correspondendo à prática social, relacionado a contextos de uso e com objetivos diversos, segundo uma visão de letramento ideológico (Street, 1984). Não o concebemos como conjunto de competências e habilidades empregadas na produção e decodificação de textos (Barton e Hamilton, 2012), entendida como letramento autônomo (Street, 1984).

Apesar disso, buscamos compreender o que as adjetivações significavam na $\mathrm{BNCC}$, ou seja, qual a concepção de cada componente curricular. Na área de Ciências, "letramento científico" é definindo como "a capacidade de compreender e interpretar o mundo, mas também de transformá-lo com base nos aportes teóricos e processuais das ciências"(Brasil, 2017, p. 319, grifos nossos). Ao considerar os modelos de letramento propostos por Street (1984), o emprego desse termo ocorre pelo viés ideológico, já que "letramento é uma forma socialmente construída [sua] constituição depende de formações políticas e ideológicas, sendo estas também responsáveis por suas consequências" (Street, 1984, p. 65, tradução nossa). Verifica-se que a noção não se limita ao conhecimento técnico e teórico da área, mas, sim, à compreensão e à interpretação do mundo, a fim de transformá-lo.

Conforme Holdbrook e Rannikmae (2009), os estudos do letramento científico procuram formar indivíduos que, ao tomarem decisões, estabeleçam o elo entre conhecimentos técnicos e a prática social de uso. Segundo Silva et al. (2018, p. 88-89), não há um consenso sobre as definições de ciência, mas, de forma geral, assim como os autores, cremos que ela não se limita à transmissão de técnicas desarticuladas das realidades, "pois a própria ciência se constrói na história e na sociedade".

Ademais, de acordo com o documento, "apreender ciência não é a finalidade última do letramento, mas, sim, o desenvolvimento da capacidade de atuação no e sobre o mundo, importante ao exercício pleno da cidadania" (Brasil, 2017, p. 319, 
grifos nossos). Assim, o modelo ideológico opõe-se ao autônomo, no sentido de que o letramento é concebido como um conjunto de práticas sociais em seus contextos, e não mais como habilidades de âmbito universal (Street, 1984).

Algumas práticas que são consideradas pelo letramento científico, no documento são: atividades de campo, manejo de dados, discussões etc. Seria por meio delas que os alunos iriam lidar com o texto escrito, visando às práticas sociais de emprego da língua, dialogando com "uma linha de pensamento que considera que a ciência esteja associada a questões sociais" (Silva et al., 2018, p. 88). Os autores, em pesquisa com acadêmicos de licenciatura, verificaram que muitos compreendem ciência como meio de solucionar problemas e forma de reprodução de conhecimentos, fatos questionados pelos estudiosos. Conforme Silva et al. (2016, p. 12), os estudos do letramento científico tiveram início "há mais de quatro décadas no campo do Ensino de Ciências", mas compreendem "letramento científico como práticas investigativas informadas pela escrita em função da produção de conhecimentos necessários ao desenvolvimento humano [...] a exemplo das práticas de formação de professores" (Silva et al., 2016, p. 14, grifos nossos).

Hoje, podemos encontrar novas discussões sobre o letramento científico em outros domínios que não só nas Ciências. $\mathrm{Na}$ leitura do documento, o termo "científico" restringiu-se aos trabalhos da área, fazendo-nos questionar a respeito do que sejam o "letramento científico" e a ciência. Ao defini-lo como "capacidade de compreender e interpretar o mundo, mas também de transformá-lo com base nos aportes teóricos e processuais das ciências"(Brasil, 2017, p. 321), questionamos se o fato de compreender, interpretar e transformar o mundo não poderia também ser realizado em outras áreas, pois produzem ciência. Na pesquisa de Silva et al. (2018), os entrevistados de Educação Física e Letras, na tentativa de explicar o que era ciência, voltaram-se às Ciências da Natureza citando exemplos de outras áreas. Além disso, nem mesmo os professores de língua nem os demais entrevistados consideraram os estudos da linguagem como lócus de produção de ciência.

Fuza (2015, p. 64) destaca que, com o tempo, teorias são revistas na tentativa de buscar a ciência plural. Logo, não é possível traçar "concepções universais de ciência, pois o interesse maior é o da emancipação do sujeito em relação à sua natureza ou a limitações sociais, envolvendo concepções diversas”. Com efeito, verificamos a limitação do entendimento de letramento científico expresso pela $\mathrm{BNCC}$, pois apenas na área de Ciências ele é mencionado. Ao refletir sobre a formação docente inicial, urge a amplitude da discussão sobre o fazer científico, principalmente nas licenciaturas.

$\mathrm{Na}$ área de Matemática, aborda-se "letramento matemático", compreendido como a "capacidade individual de formular, empregar e interpretar a matemática em uma variedade de contextos [...] raciocinar matematicamente e utilizar conceitos, procedimentos, fatos eferramentas matemáticas para descrever, explicar e predizer fenômenos" (Brasil, 2017, p. 264, grifos nossos). Mais uma vez, há o diálogo com os pressupostos ideológicos, já que não basta o domínio da técnica de formulação da matemática, mas também seu emprego e sua interpretação em contextos. A partir disso é que será possível auxiliar "os indivíduos a reconhecer o papel que a matemática exerce no 
mundo e para que cidadãos construtivos, engajados e reflexivos possam fazer julgamentos bem fundamentados e tomar as decisões" (Brasil, 2017, p. 264, grifos nossos).

Segundo Fonseca (2004, p. 27), há diferentes designações para tratar de uma noção de Matemática como uma prática sociocultural: "alfabetismo, alfabetismo funcional, letramento [...] numeramento [...]”. O autor, assim como a BNCC, emprega "letramento", em função da concepção de "habilidades matemáticas como constituintes das estratégias de leitura que precisam ser implementadas para uma compreensão da diversidade de textos que a vida social nos apresenta" (Fonseca, 2004, p. 27).

Toda a discussão, centrada em uma postura reflexiva sobre linguagem na Matemática, apresenta a necessidade de uma nova postura para professores e alunos. Estes, na maioria das vezes, acreditam que na aula de Matemática não é preciso ler e refletir, mas apenas se chegar a respostas lógicas. Com essa nova proposta do documento, essas ideias precisam ser repensadas, pois o aluno deve saber utilizar seus conhecimentos em problemas reais. Para o Instituto Nacional de Estudos e Pesquisas Educacionais Anísio Teixeira (INEP):5 "O letramento matemático [...] não se limita ao conhecimento [...] dos procedimentos matemáticos, ainda que os inclua [...] As competências matemáticas implicam na combinação desses elementos para satisfazer as necessidades da vida real dos indivíduos na sociedade".

Para Santos et al. (2017, p. 4), a fim de desenvolver habilidades matemáticas, é necessário que o sujeito se constitua como ser letrado, ou seja, que entenda e aplique práticas de leitura e escrita para "resolver problemas não somente escolares, mas de práticas cotidianas [...] ações relacionadas aos diferentes usos socioculturais da matemática". Por esse motivo é que a BNCC afirma que os currículos devem aproximar as temáticas de matemáticas ao universo da cultura, das contextualizações.

$\mathrm{Na}$ área de Linguagens, o documento emprega a noção dos "novos" e dos “multiletramentos". Segundo Rojo (2012), pela necessidade do trabalho com a diversidade cultural e linguística na escola, passou-se a pensar em uma pedagogia dos multiletramentos, em 1996, a partir de um manifesto resultante de um colóquio do Grupo de Nova Londres - grupo de pesquisadores dos letramentos. No manifesto: "A pedagogy of multiliteracies: designing social futures", o grupo tratava da necessidade de a escola abordar "novos letramentos emergentes na sociedade contemporânea, em grande parte - mas não somente - devidos às novas TICS, e de levar em conta e incluir nos currículos a grande variedade de culturas" (Rojo, 2012, p. 12).

O conceito de "multiletramentos" refere-se à "multiplicidade cultural das populações" "à multiplicidade semiótica de constituição dos textos", por meio dos quais os sujeitos se informam e se comunicam (Rojo, 2012, p. 13), abordando noções culturais e de multiplicidade de linguagens em textos impressos, audiovisuais, digitais ou não. Os textos compostos de muitas linguagens (semioses) exigem "capacidades

5 Disponível em: http://download.inep.gov.br/download/internacional/pisa/2010/letramento_matematico.pdf. Acesso em: 30 dez. 2018. 
e práticas de compreensão e produção de cada uma delas (multiletramentos) para fazer significar" (Rojo, 2012, p. 19).

Aos multiletramentos vincula-se a diversidade cultural, contemplando-se "o cânone, o marginal, o culto, o popular [...] de forma a garantir uma ampliação de repertório e uma interação e trato com o diferente" (Brasil, 2017, p. 68). Por isso, na BNCC, no componente Língua Portuguesa, sugere-se a exploração das culturas locais, das culturas juvenis, valorizando o resgate, a valoração e a divulgação da produção artística dos jovens, dos indígenas etc.

Na BNCC, a ausência de explicação/definição do que seja "multiletramento" pode ocasionar dúvidas ao professor, já que não se esclarece como se daria esse trabalho, expondo-se que o sujeito se constitui como "usuário da língua/das linguagens":

Essa consideração dos novos e multiletramentos; e das práticas da cultura digital no currículo não contribui somente para que uma participação mais efetiva e crítica nas práticas contemporâneas de linguagem por parte dos estudantes possa ter lugar, mas permite também que se possa ter em mente mais do que um "usuário da lingua/ das linguagens", na dirę̧ão do que alguns autores vão denominar de designer: alguém que toma algo que já existe [...] produzindo novos sentidos. (Brasil, 2017, p. 68, grifos nossos)

Diante do exposto, verificam-se as características dos textos nos multiletramentos (Rojo, 2012, p. 23): “(a) eles são interativos; [...] colaborativos; (b) eles fraturam e transgridem as relações de poder estabelecidas [...]; (c) eles são híbridos, fronteiriços, mestiços (de linguagens, modos, mídias e culturas)".

$\mathrm{Na}$ Língua Inglesa, acredita-se que há uma ampliação da visão de letramento, já que é "concebida também nas práticas sociais do mundo digital - no qual saber a lingua inglesa potencializa as possibilidades de participação e circulação - que aproximam e entrelaçam diferentes semioses e linguagens” (Brasil, 2017 , p. 240, grifos nossos).

Independentemente do termo empregado pelas áreas ("letramento científico"; "letramento matemático"; "multiletramentos"), a noção de letramento se volta ao modelo ideológico, compreendendo-se as práticas de escrita como formas socialmente construídas, dependentes de aspectos políticos e ideológicos. A noção não tem como foco apenas o saber teórico da área, mas a sua compreensão, possibilitando o agir dos sujeitos. Desse modo, questionamo-nos: Qual a viabilidade de trabalhar com (multi)letramentos na escola, nas diferentes áreas do conhecimento? Como formamos professores para isso? Hoje já delimitamos lacunas e possibilidades na formação inicial do professor quanto ao digital (Miranda, 2016; Silva e Fuza, 2017), fatos que nos fazem refletir a respeito do modo como as ideias, principalmente as relacionadas aos (multi)letramentos, serão abordadas em sala de aula, já que a noção pode ser de letramento ideológico, mas a prática desenvolvida revelar-se ancorada em modelo autônomo.

Em outros componentes do documento não há menção direta ao termo "letramento", porém, por meio da análise de seus dizeres, é possível depreendê-lo. $\mathrm{Na}$ Arte, as manifestações artísticas não se reduzem “à mera aquisição de códigos 
e técnicas. A aprendizagem de Arte precisa alcançar a experiência e a vivência artísticas como prática social"(Brasil, 2017, p. 190). Os termos "experiência", "vivência" e, principalmente, "prática social” evocam um uso ideológico da linguagem, ou seja, dos letramentos.

$\mathrm{Na}$ Geografia, a ênfase está no pensamento espacial e no "raciocínio geográfico" (Brasil, 2017, p. 357). Este significa "entender o mundo, a vida e o cotidiano" (Trevisan, s/d.), para que o sujeito possa atuar criticamente em âmbito social. Há, como práticas letradas, leitura e produção de mapas e gráficos, "alfabetização cartográfica", uso de diferentes linguagens etc.

Quanto ao ensino de História, a BNCC aponta a necessidade de o aluno aprender a relacionar fatos do presente e do passado, criticamente. É preciso "transformar a história em ferramenta a serviço de um discernimento maior sobre as experiências humanas e das sociedades em que se vive” (Brasil, 2017, p. 401). Os alunos devem aprender e discutir sobre os fatos dentro de um contexto social maior, de modo que pergunte, argumente, crie hipóteses etc.

No Ensino Religioso, relaciona-se a disciplina a outros campos de conhecimento: "Analisar as relações entre as tradições religiosas e os campos da cultura, da política, da economia, da saúde, da ciência, da tecnologia e do meio ambiente" (Brasil, 2017, p. 435), levando-nos a pensar que essas análises e relações se dão por meio de práticas sociais, práticas de letramentos.

De forma geral, independentemente do emprego ou não do termo "letramento", o documento, ao longo de seus componentes, revela uma visão de letramento ideológico, considerando o uso da linguagem como prática social, contextualizada, com objetivos diversos. No entanto, é elementar considerar que as noções não garantem práticas efetivas no contexto escolar, já que o desenvolvimento real delas passa por diversas instâncias e sujeitos, como contextos, alunos e professores que ali atuam. Tão logo, compreender outros elementos que acarretam no entendimento das práticas letradas pela BNCC é indispensável, como o entendimento sobre as tecnologias (digitais) envolvidas e os gêneros discursivos que as constroem.

\section{ENTENDIMENTO SOBRE TECNOLOGIAS DIGITAIS NA BNCC}

Ao entendermos a BNCC como potencial modificadora de formas de atuação de professores e, portanto, incidente em (im)possíveis mudanças em sua formação, percebemos um posicionamento do documento: o necessário domínio de tecnologias digitais pelo docente. Desde sua "Introdução", deparamo-nos com referências ao digital. Entre as dez competências gerais apresentadas para todas as áreas do conhecimento, quatro delas tematizam a questão:

1. Valorizar e utilizar os conbecimentos historicamente construidos sobre o mundo físico, social, cultural e digital para entender e explicar a realidade, continuar aprendendo e colaborar para a construção de uma sociedade justa, democrática e inclusiva. 
2. Exercitar a curiosidade intelectual e recorrer à abordagem própria das ciências, incluindo a investigação, a reflexão [...] para investigar causas, elaborar e testar hipóteses, formular e resolver problemas e criar soluçôes (inclusive tecnológicas) com base nos conhecimentos das diferentes áreas. [...]

4. Utilizar diferentes linguagens - verbal (oral ou visual-motora, como Libras, e escrita), corporal, visual, sonora e digital - , bem como conhecimentos das linguagens artística, matemática e científica, para se expressar e partilhar informações [...] em diferentes contextos e produzir sentidos que levem ao entendimento mútuo.

5. Compreender, utilizar e criar tecnologias digitais de informação e comunicą̧ão de forma crítica, significativa, reflexiva e ética nas diversas práticas sociais (incluindo as escolares) para se comunicar, acessar e disseminar informações, produzir conhecimentos, resolver problemas e exercer protagonismo e autoria na vida pessoal e coletiva. (Brasil, 2017, p. 9, grifos nossos)

Na primeira competência, o digital é visto como um universo e se integraria a outros coexistentes pelos quais transitam os indivíduos, o que se aproxima à ideia de ciberespaço (Lévy, 1999). Apregoa-se que os estudantes deveriam valer-se do saber já desenvolvido sobre esses "mundos" para atuar socialmente.

$\mathrm{Na}$ segunda competência, as tecnologias são ferramentas para se agir concretamente. Diferentemente da primeira acepção, tecnologia, aqui, aparece como uma generalização que pode compreender o digital ou não. Assim, tecnológico está no sentido de técnico, e não necessariamente de tecnologia digital. Buzato (2010, p. 303) esclarece que a ideia de tecnologia é "Entendida não como corporificação de um saber científico em máquina, mas como conjunto de técnicas racionais e utensílios que, articulados, constituem certo modo de trazer ao mundo algo que antes não havia". Interpretamos que o professor precisará saber ensinar uso e função de ferramentas técnicas (que podem ser digitais).

Na quarta competência, o digital é evocado com nova conotação: a de linguagem. As áreas necessitam empregar diferentes linguagens, ou seja, o entendimento não é mais como espaço ou ferramenta, mas semiose (Corrêa, 2018; Rojo, 2017). Novamente, o papel do professor é de alguém que conheça e promova o uso da multissemiose/múltiplas linguagens na escola, entendendo-se que uma delas é a digital. Ao considerar que "a linguagem verbal tem presença incontornável tanto na produção quanto na leitura dos produtos das tecnologias digitais"(Corrêa, 2018, p. 122), reforça-se a necessidade de distinção da(s) concepção(ões) de letramento(s), tal como fizemos na subseção precedente.

$\mathrm{Na}$ quinta competência, entende-se o digital como TDIC e uma abordagem delas, dentro e fora da escola, aos moldes de uma "pedagogia dos multiletramentos", fundamentada na diversidade de letramentos (Rojo, 2012). Os professores deverão ser aqueles que promovam usos das TDIC, mediando o desenvolvimento das práticas por meio de diferentes tecnologias, incluindo-se as digitais. 
Para além da alta quantidade de menções explícitas à presença de tecnologias (digitais) no ensino, essa "Introdução" traz diferentes noções delas, levando-nos a compreendê-las como caminhos que são colocados para a atuação do professor. Ao serem delineados, cremos que poderemos contribuir para reflexões sobre a formação docente que se repercutem no ensino escolar com tecnologias digitais. Com efeito, é preciso despertar a atenção dos professores para a discussão dos valores atribuídos ao digital, nas diferentes áreas, diante do novo documento oficial para o ensino, incluindo-se os formadores de professores, papel no qual nos identificamos.

Diante disso, apresentamos como essas concepções de tecnologias digitais são postas nas várias áreas e nos componentes curriculares e o que esses entendimentos poderão revelar sobre a atuação dos professores, ao percebermos seu aparecimento, principalmente como: (A) Tecnologias digitais como espaço ou mundo; (B) Tecnologias digitais como ferramenta ou técnica; (C) Tecnologias digitais como linguagem ou objeto discursivo; (D) Tecnologias digitais como TDIC para se agir socialmente.

Em análise de todo o documento, não somente as "competências gerais" apresentam diferenças na concepção sobre o que seriam as tecnologias digitais, como também as próprias áreas entre si e uma mesma área divergem. Diante disso, orientadas pelas principais tendências - (A), (B), (C) e (D) - identificadas, apresentamos os achados no Quadro 1.

Quadro 1-Concepções de tecnologias digitais nas áreas e nos componentes curriculares.

\begin{tabular}{|c|c|c|c|}
\hline $\begin{array}{c}\text { Concepção } \\
\text { detecnologia }\end{array}$ & Áreas & Exemplos & $\begin{array}{c}\text { Componentes } \\
\text { curriculares }\end{array}$ \\
\hline \multirow{3}{*}{ A } & Linguagens & $\begin{array}{l}\text { "Valorizar e utilizar os conhecimentos } \\
\text { historicamente construídos sobre o mundo físico, } \\
\text { social, cultural e digital" (Brasil, 2017, p. 10). } \\
\text { "uso de hipertextos e hiperlinks, dentre outros, } \\
\text { presentes nos textos que circulam em contexto } \\
\text { digital" (Brasil, 2017, p. 75). } \\
\text { "meios digitais" (Brasil, 2017, p. 242). }\end{array}$ & $\begin{array}{l}\text { Língua Portuguesa } \\
\text { Língua Inglesa }\end{array}$ \\
\hline & $\begin{array}{l}\text { Ciências da } \\
\text { Natureza }\end{array}$ & $\begin{array}{l}\text { "Planejar e realizar atividades de campo } \\
\text { (experimentos, observações, leituras, visitas, } \\
\text { ambientes virtuais)"(Brasil, 2017, p. 323). }\end{array}$ & Ciências \\
\hline & $\begin{array}{l}\text { Ciências } \\
\text { Humanas }\end{array}$ & $\begin{array}{l}\text { “compreendendo a transformação do espaço } \\
\text { em território usado - espaço da ação concreta } \\
\text { e das relações desiguais de poder, considerando } \\
\text { também o espaço virtual proporcionado } \\
\text { pela rede mundial de computadores e das } \\
\text { geotecnologias" (Brasil, 2017, p. 379). } \\
\text { "posicionar-se e intervir no mundo } \\
\text { contemporâneo" (Brasil, 2017, p. 400). }\end{array}$ & $\begin{array}{l}\text { Geografia } \\
\text { História }\end{array}$ \\
\hline
\end{tabular}


Quadro 1-Continuação.

\begin{tabular}{|c|c|c|c|}
\hline $\begin{array}{c}\text { Concepção } \\
\text { detecnologia }\end{array}$ & Áreas & Exemplos & $\begin{array}{c}\text { Componentes } \\
\text { curriculares }\end{array}$ \\
\hline \multirow{5}{*}{ B } & $\begin{array}{l}\text { Ensino } \\
\text { Religioso }\end{array}$ & $\begin{array}{l}\text { "Analisar as relações entre as tradições } \\
\text { religiosas e os campos da cultura, da política, da } \\
\text { economia, da saúde, da ciência, da tecnologia e } \\
\text { do meio ambiente" (Brasil, 2017, p. 437). }\end{array}$ & Ensino Religioso \\
\hline & Linguagens & $\begin{array}{l}\text { "ferramentas digitais para expandir as formas de } \\
\text { produzir sentidos [...], aprender e refletir sobre } \\
\text { o mundo e realizar diferentes projetos autorais" } \\
\text { (Brasil, 2017, p. 85). } \\
\text { "Identificar as transformações nas características } \\
\text { dos jogos eletrônicos [...] e nas respectivas } \\
\text { exigências corporais colocadas por esses } \\
\text { diferentes tipos de jogos" (Brasil, 2017, p. 233). }\end{array}$ & $\begin{array}{l}\text { Língua Portuguesa } \\
\text { Educação Física } \\
\text { Língua Inglesa }\end{array}$ \\
\hline & Matemática & $\begin{array}{l}\text { "Utilizar processos e ferramentas matemáticas, } \\
\text { inclusive tecnologias digitais disponíveis, para } \\
\text { modelar e resolver problemas" (Brasil, 2017, } \\
\text { p. 265). } \\
\text { "Os alunos devem dominar também o cálculo } \\
\text { de porcentagem, porcentagem de porcentagem, } \\
\text { juros, descontos e acréscimos, incluindo o uso } \\
\text { de tecnologias digitais" (Brasil, 2017, p. 267). } \\
\text { "Construção de retas paralelas e } \\
\text { perpendiculares, fazendo uso de réguas, } \\
\text { esquadros e softwares" (Brasil, 2017, p. 300). } \\
\text { "medidas da abertura de ângulos, por meio de } \\
\text { transferidor e/ou tecnologias digitais" (Brasil, } \\
\text { 2017, p. 301). } \\
\text { "Resolver e elaborar problemas, envolvendo } \\
\text { cálculo de porcentagens, incluindo o uso de } \\
\text { tecnologias digitais" (Brasil, 2017, p. 313). }\end{array}$ & Matemática \\
\hline & $\begin{array}{l}\text { Ciências da } \\
\text { Natureza }\end{array}$ & $\begin{array}{l}\text { "Desenvolver e utilizar ferramentas, inclusive } \\
\text { digitais, para coleta, análise e representação de } \\
\text { dados" (Brasil, 2017, p. 323). }\end{array}$ & Ciências \\
\hline & $\begin{array}{l}\text { Ciências } \\
\text { Humanas }\end{array}$ & $\begin{array}{l}\text { "Desenvolver o pensamento espacial, fazendo } \\
\text { uso das linguagens cartográficas e iconográficas, } \\
\text { de diferentes gêneros textuais e das } \\
\text { geotecnologias para a resolução de problemas } \\
\text { que envolvam informações geográficas" (Brasil, } \\
\text { 2017, p. 364). } \\
\text { “avaliar ações e propor perguntas e soluções } \\
\text { (inclusive tecnológicas) para questões que } \\
\text { requerem conhecimentos científicos da } \\
\text { Geografia" (Brasil, 2017, p. 364). } \\
\text { "Produzir, avaliar e utilizar tecnologias digitais } \\
\text { de informação e comunicação de modo } \\
\text { crítico, ético e responsável, compreendendo } \\
\text { seus significados para os diferentes grupos ou } \\
\text { estratos sociais" (Brasil, 2017, p. 400). }\end{array}$ & $\begin{array}{l}\text { Geografia } \\
\text { História }\end{array}$ \\
\hline
\end{tabular}


Quadro 1-Continuação.

\begin{tabular}{|c|c|c|c|}
\hline $\begin{array}{l}\text { Concepção } \\
\text { detecnologia }\end{array}$ & Áreas & Exemplos & $\begin{array}{c}\text { Componentes } \\
\text { curriculares }\end{array}$ \\
\hline \multirow[t]{2}{*}{$\mathrm{C}$} & Linguagens & $\begin{array}{c}\text { "Utilizar diferentes linguagens — verbal (oral ou visual- } \\
\text { motora, como Libras, e escrita), corporal, visual, sonora e } \\
\text { digital" (Brasil, 2017, p. 63). } \\
\text { "Analisar e utilizar as formas de composição dos gêneros } \\
\text { jornalísticos da ordem do relatar, tais como notícias (pirâmide } \\
\text { invertida no impresso X blocos noticiosos hipertextuais e } \\
\text { hipermidiáticos no digital)" (Brasil, 2017, p. 145). } \\
\text { "Identificar as transformações nas características dos } \\
\text { jogos eletrônicos em função dos avanços das tecnologias } \\
\text { e nas respectivas exigências corporais colocadas por esses } \\
\text { diferentes tipos de jogos" (Brasil, 2017, p. 233). } \\
\text { "Utilizar novas tecnologias, com novas linguagens e modos } \\
\text { de interação, para pesquisar, selecionar, compartilhar, } \\
\text { posicionar-se e produzir sentidos em práticas de letramento } \\
\text { na língua" (Brasil, 2017, p. 244). } \\
\text { “Comunicar-se na língua inglesa, por meio do uso variado de } \\
\text { linguagens em mídias impressas ou digitais"(Brasil, 2017,p. 244). }\end{array}$ & $\begin{array}{c}\text { Língua Portuguesa } \\
\text { Língua Inglesa } \\
\text { Educação Física }\end{array}$ \\
\hline & $\begin{array}{l}\text { Ciências da } \\
\text { Natureza }\end{array}$ & $\begin{array}{l}\text { "Relatar informações de forma oral, escrita e multimodal" } \\
\text { (Brasil, 2017, p. 321). }\end{array}$ & Ciências \\
\hline \multirow{4}{*}{$\mathrm{D}$} & Linguagens & $\begin{array}{l}\text { "Compreender, utilizar e criar tecnologias digitais de informação } \\
\text { e comunicação de forma crítica, significativa, reflexiva e ética nas } \\
\text { diversas práticas sociais"(Brasil, 2017,p. 63). } \\
\text { "verbete de enciclopédia digital colaborativa, relato } \\
\text { (multimidiático) de campo, podcast ou vlog científico, vídeos } \\
\text { de diferentes tipos [...]” (Brasil, 2017, p. 153). } \\
\text { "relações e articulações entre as diferentes linguagens e suas } \\
\text { práticas, inclusive aquelas possibilitadas pelo uso das novas } \\
\text { tecnologias de informação e comunicação"(Brasil, 2017, p. 195). } \\
\text { "Explorar ambientes virtuais da informação e socialização, } \\
\text { analisando a qualidade e a validade das informações } \\
\text { veiculadas"(Brasil, 2017, p. 261). }\end{array}$ & $\begin{array}{c}\text { Língua Portuguesa } \\
\text { Arte } \\
\text { Língua Inglesa }\end{array}$ \\
\hline & $\begin{array}{l}\text { Ciências da } \\
\text { Natureza }\end{array}$ & $\begin{array}{l}\text { "Utilizar diferentes linguagens e tecnologias digitais de } \\
\text { informação e comunicação para se comunicar, acessar e } \\
\text { disseminar informações, produzir conhecimentos e resolver } \\
\text { problemas das Ciências da Natureza" (Brasil, 2017, p. 322). } \\
\text { "Associar a produção de medicamentos e outros materiais sintéticos } \\
\text { ao desenvolvimento científico e tecnológico"(Brasil, 2017,p. 343). } \\
\text { "Analisar historicamente o uso da tecnologia, incluindo a digital, } \\
\text { nas diferentes dimensões da vida humana"(Brasil, 2017,p. 345). }\end{array}$ & Ciências \\
\hline & $\begin{array}{l}\text { Ciências } \\
\text { Humanas }\end{array}$ & $\begin{array}{l}\text { "Analisar a influência e o papel das redes de transporte e comunicação } \\
\text { na configuração do território brasileiro"(Brasil, 2017,p.385). } \\
\text { "posicionar-se e intervir no mundo contemporâneo" } \\
\text { (Brasil, 2017, p. 400). } \\
\text { "Analisar as transformações nas relações políticas locais e } \\
\text { globais geradas pelo desenvolvimento das tecnologias digitais } \\
\text { de informação e comunicação" (Brasil, 2017, p. 431). }\end{array}$ & $\begin{array}{l}\text { Geografia } \\
\text { História }\end{array}$ \\
\hline & $\begin{array}{c}\text { Ensino } \\
\text { Religioso }\end{array}$ & $\begin{array}{l}\text { "Analisar as formas de uso das mídias e tecnologias pelas } \\
\text { diferentes denominações religiosas" (Brasil, 2017, p. 457). }\end{array}$ & Ensino Religioso \\
\hline
\end{tabular}

Fonte: Brasil (2017).

Elaboração das autoras. 
Apresentamos no Quadro 2 uma síntese das recorrências das concepções das tecnologias nas respectivas áreas com base em nossas interpretações: ${ }^{6}$

Quadro 2 - Síntese das concepções de tecnologias digitais nas áreas.

\begin{tabular}{|l|c|c|c|c|}
\hline Áreas & $\begin{array}{c}(\mathrm{A}) \\
\text { Tecnologias } \\
\text { digitais como } \\
\text { espaço ou mundo }\end{array}$ & $\begin{array}{c}(\mathrm{B}) \\
\text { Tecnologias } \\
\text { digitais como } \\
\text { ferramenta ou } \\
\text { técnica }\end{array}$ & $\begin{array}{c}(\mathrm{C}) \\
\text { Tecnologias } \\
\text { digitais como } \\
\text { linguagem ou } \\
\text { objeto discursivo }\end{array}$ & $\begin{array}{c}\text { (D) } \\
\text { Tecnologias } \\
\text { digitais como } \\
\text { TDIC para se } \\
\text { agir socialmente }\end{array}$ \\
\hline Linguagens & $\sqrt{ }$ & $\sqrt{ }$ & $\sqrt{ }$ & $\sqrt{ }$ \\
\hline Ciências da Natureza & $\sqrt{ }$ & $\sqrt{ }$ & $\varnothing$ & $\sqrt{ }$ \\
\hline Ciências Humanas & $\sqrt{ }$ & $\sqrt{ }$ & $\varnothing$ & $\varnothing$ \\
\hline Matemática & $\varnothing$ & $\varnothing$ & $\varnothing$ & $\sqrt{ }$ \\
\hline Ensino Religioso & $\sqrt{ }$ & & & \\
\hline
\end{tabular}

Fonte: Brasil (2017).

Elaboração das autoras.

Os dados apresentados revelam a oscilação na concepção de tecnologias digitais. As áreas com maior diversidade de sentidos são Linguagens e Ciências da Natureza. Por exemplo, nas Ciências da Natureza as tecnologias são espaço (A) quando se postula: "Planejar e realizar atividades de campo [...]" (Brasil, 2017, p. 323); então se voltam para (B): "Desenvolver e utilizar ferramentas, inclusive digitais, para coleta, análise e representação de dados” (Brasil, 2017, p. 323); depois para $(\mathrm{C})$, entendidas quando, entre a multimodalidade, contempla-se o digital: "Relatar informações de forma oral, escrita e multimodal" (Brasil, 2017, p. 321); e, por fim, (D): "Utilizar diferentes linguagens e tecnologias digitais de informação e comunicação para se comunicar, acessar e disseminar informações[...]" (Brasil, 2017 , p. 322). As definições partem de um entendimento micro de tecnologia até alcançar o macro, que abarque a noção das múltiplas linguagens, em âmbito social.

As diferentes abordagens nos componentes podem ocorrer em virtude de as áreas conceberem os conteúdos e a linguagem, conforme suas especificidades. Além disso, a BNCC é um documento redigido por muitos "redatores"” (Brasil, 2017, p. 460) com realidades sociais distintas, o que pode ter influenciado diretamente no texto.

A BNCC diz propor a compreensão, a utilização e a criação de tecnologias digitais de forma significativa, reflexiva e ética, para que o aluno produza conhecimento, resolva problemas, atribuindo ao aluno papel mais responsável, autônomo e colaborativo. No Quadro 2, das cinco áreas, quatro tratam da concepção (D), o que pode demarcar a preocupação em entender as tecnologias para agir socialmente, pressupondo a diversi-

6 Realizamos análise interpretativa dos dados à luz de nossa posição de professoras-formadoras-pesquisadoras, fato que reforça a possibilidade de novas interpretações.

7 Nas duas primeiras versões, havia 116 redatores. Para a versão final, o Comitê Gestor indicou "grupo de especialistas responsável pela revisão dos documentos anteriormente elaborados, com base em insumos das consultas públicas e pareceres técnicos". Disponível em: http://basenacionalcomum.mec.gov.br/a-base. Acesso em: 10 ago. 2019. 
dade de letramentos (Rojo, 2012). Os professores atuam na promoção do emprego das TDIC por meio de diferentes tecnologias, incluindo-se as digitais, independentemente da área de conhecimento. Nas perceptivas de letramento, discutidas anteriormente, há na área de Ciências o "letramento científico" e nas Linguagens, os "Multiletramentos", fato que pode justificar o foco no âmbito social, presente nesta discussão sobre o digital.

As áreas que apresentam menos variação nas concepções de tecnologias digitais são as de Ensino Religioso, com (A) e (D), e de Matemática, com (B). No primeiro caso, embora o termo digital não seja destacado, pode-se inferir que as tecnologias digitais estariam como campo, ao se explicar que uma das competências específicas da área é "Analisar as relações entre as tradições religiosas e os campos da cultura [...]" (Brasil, 2017, p. 437). Além dessa, há também a noção de tecnologias digitais como forma de atuação social em uma das habilidades específicas: "Analisar as formas de uso das mídias e tecnologias pelas diferentes denominações religiosas" (Brasil, 2017, p. 457). Novamente, uma oscilação na interpretação do conceito.

Na Matemática, a concepção predominante é (B), com o emprego, por exemplo, de ferramentas que apoiam a aprendizagem dos conteúdos (Quadro 1). Na seção anterior, a área de Matemática abordou a expressão "letramento matemático", indicando que é preciso ir além do domínio de técnicas. Ressaltamos aqui uma possibilidade ambígua de interpretação dos leitores, já que a área trata de letramento, em um viés ideológico, mas ao abordar o digital apresenta uma perspectiva que poderá ser entendida por aqueles como tecnicista. Diante disso, cabe ao professor e/ou à escola perceber o documento como passível de ajustes, pensando na elaboração de seu próprio currículo, dado que é considerado algo em construção. Possivelmente, será no contexto escolar, à luz da BNCC, que o currículo adquirirá caráter interdisciplinar e refletirá, por exemplo, a remoção das barreiras entre as disciplinas, possibilitando um olhar para o saber matemático, mediado pelo digital, que não se volte apenas para o técnico, mas para o social. A problemática é que o documento não aponta encaminhamentos metodológicos para lidar com os conteúdos, apenas os delimita, deixando totalmente a cargo dos estados e, consequentemente, das instituições esse trabalho.

Sobre as concepções de tecnologia, estas indicam também abordagens diversas para o ensino em todas as áreas, uma vez que inserir o aluno em um universo tecnológico (concepção A) para usar e/ou produzir ferramentas tecnológicas (concepção B), para ler e produzir textos em diferentes semioses/linguagens (concepção C) ou para agir socialmente por meio de TDIC (concepção D), culmina em formas distintas de trabalho em sala de aula e na própria mediação do professor, que por sua vez precisa ter claro quais são seus objetivos e objetos de ensino.

Assim, não é suficiente que haja um documento normativo postulando a introdução de tecnologias digitais no ensino para melhorá-lo automaticamente. Até porque as próprias concepções de tecnologias digitais da BNCC são variáveis e muitas vezes conflitantes. É preciso ponderar sobre a questão, pois: "seria pretensioso imaginar que é possível, do ponto de vista da linguagem e nos limites das atividades escolares, dar conta de uma didatização minimamente aprofundada de cada um deles" [dos meios de comunicação de natureza digital] (Corrêa, 2018, p. 122).

A questão que se coloca é como se apropriar das tecnologias digitais e sob quais concepções para se desenvolver práticas de ensino e aprendizagem em 
nossas áreas de atuação? Se pensarmos do âmbito do ensino de língua materna, a incorporação delas, seja em qual acepção for, tem sido avaliada. Como já advertia Buzato (2010, p. 299-300), o blog escolar "pode não passar de um mero repositório [...] de reificações oriundas de uma prática não fronteiriça [...], isto é, uma prática monológica constrangida por designs didáticos e curriculares autoritários centrados numa interpretação global do que seria um problema local".

A presença das tecnologias digitais, portanto, pode apenas perpetuar práticas tradicionais já criticadas, e essa é uma discussão que a homologação da BNCC nos suscita. Ao mesmo tempo em que sua implementação prevê reformulações na formação de professores, ela traz questionamentos sobre sua realização, pois, como observado, promover um trabalho com o digital pode ser bastante divergente. Para melhor cogitar sobre o ensino, na próxima subseção trataremos de objetos referenciados pelo documento.

\section{GÊNEROS DISCURSIVOS ASSOCIADOS AO MEIO DIGITAL PROPOSTOS NAS ÁREAS}

Nos componentes curriculares de cada área, no EFII, há espaços para a abordagem de práticas (de linguagem) para se trabalhar com o ensino dos conteúdos, seja em exemplos para se desenvolver as habilidades específicas ou mesmo nas apresentações de possibilidades de ações nas unidades temáticas. Nesse contexto, conseguimos identificar gêneros discursivos sugeridos/propostos nas áreas e a relação de muitos deles com tecnologias digitais (Rojo e Barbosa, 2015).

Antes de tratar desses gêneros e de suas implicações para o ensino, é importante mencionar que os concebemos como elementos compostos de conteúdo temático, forma composicional e estilo, então realizados em práticas de linguagem de uma esfera social (Bakhtin, 2003[1953]). Essa concepção parece estar em conformidade com a noção de uso da linguagem da BNCC e dos PCN, da área de Linguagens (Geraldi, 2015), que valoriza uma relação com práticas sociais reais nas áreas e com algumas esferas, como consta na sexta competência geral: "Valorizar a diversidade de saberes e vivências culturais e apropriar-se de conhecimentos e experiências que lhe possibilitem entender as relações próprias do mundo do trabalho e fazer escolhas alinhadas ao exercício da cidadania [...]" (Brasil, 2017, p. 9).

Ao resgatar as vivências dos alunos e a atuação social deles, o documento enfatiza práticas que se alinham à contemporaneidade com o uso de tecnologias digitais, por exemplo, em práticas de (multi)letramentos (Rojo, 2012), ainda que o desenvolvimento destas, como autônomas ou ideológicas (Street, 1984), seja igualmente possível. Assim, são trazidos diversos (e novos) gêneros para o contexto do ensino, seja de forma direta, quando o trabalho com alguns, em específico, é proposto, como em Língua Portuguesa, ou de forma indireta, quando, para se chegar a certo objeto de ensino, necessita-se deles, como na Matemática.

A partir dessa forma de inclusão dos gêneros discursivos, analisamos os dizeres de todas as áreas do documento, para encontrar sua indicação ou menção, em interseção com tecnologias digitais, visto ser a atuação em práticas contemporâneas, a forte ênfase da BNCC (Quadro 3). 
Quadro 3 - Áreas e gêneros que contemplam o digital.

\begin{tabular}{|c|c|c|c|c|}
\hline Áreas & Componentes & $\begin{array}{c}\text { Gênero(s) } \\
\text { contemplado(s) } \\
\text { em intersecção } \\
\text { com o digital }\end{array}$ & Exemplos & $\begin{array}{c}\text { Percepção sobre } \\
\text { gêneros }\end{array}$ \\
\hline \multirow{4}{*}{ Linguagens } & Língua Portuguesa & $\begin{array}{c}\text { Gêneros em } \\
\text { diferentes mídias, } \\
\text { linguagens e meios }\end{array}$ & $\begin{array}{l}\text { Podcasts, } \\
\text { petição } \\
\text { on-line, vlog, } \\
\text { charge digital, } \\
\text { gameplay, } \\
\text { fanfics etc. }\end{array}$ & $\begin{array}{c}\text { inseridos de acordo com } \\
\text { as práticas dos campos } \\
\text { de atuação; } \\
\text { diretamente indicados } \\
\text { nos campos e nas } \\
\text { habilidades específicas. }\end{array}$ \\
\hline & Arte & $\begin{array}{c}\text { Gênero em } \\
\text { manifestações } \\
\text { artísticas }\end{array}$ & $\begin{array}{l}\text { Ilustrações } \\
\text { de textos } \\
\text { diversos, } \\
\text { animações, } \\
\text { vídeos etc. }\end{array}$ & $\begin{array}{l}\text { vistos mais como } \\
\text { instrumentos do que } \\
\text { objetos de ensino; } \\
\text { aparecem maiormente } \\
\text { nas habilidades e não são } \\
\text { diretamente indicados. }\end{array}$ \\
\hline & Educação Física & $\begin{array}{c}\text { Gêneros } \\
\text { principalmente em } \\
\text { jogos eletrônicos }\end{array}$ & $\begin{array}{l}\text { Jogos } \\
\text { eletrônicos, } \\
\text { análise de } \\
\text { diferentes } \\
\text { meios, } \\
\text { discussão etc. }\end{array}$ & $\begin{array}{l}\text { aparecem como apoio para } \\
\text { objetos de conhecimento } \\
\text { (como jogos); } \\
\text { aparecem como meios } \\
\text { para desenvolver } \\
\text { habilidades em função } \\
\text { do desenvolvimento de } \\
\text { tecnologias digitais; } \\
\text { não são diretamente } \\
\text { indicados. }\end{array}$ \\
\hline & Língua Inglesa & $\begin{array}{c}\text { Gêneros em práticas } \\
\text { sociais }\end{array}$ & $\begin{array}{l}\text { Chats, } \\
\text { mensagens } \\
\text { instantâneas, } \\
\text { tweets, fóruns } \\
\text { on-line etc. }\end{array}$ & $\begin{array}{c}\text { são diretamente } \\
\text { indicados nas } \\
\text { habilidades específicas. }\end{array}$ \\
\hline Matemática & Matemática & $\begin{array}{l}\text { Proposta de trabalho } \\
\text { com gêneros variados }\end{array}$ & $\begin{array}{l}\text { Planilhas } \\
\text { eletrônicas, } \\
\text { consulta a sites, } \\
\text { figuras etc. }\end{array}$ & $\begin{array}{c}\text { ferramentas para } \\
\text { se desenvolver as } \\
\text { habilidades específicas; } \\
\text { aparecem de forma } \\
\text { direta e indireta como } \\
\text { recomendação para } \\
\text { [produção e análise] de } \\
\text { gêneros que requerem o } \\
\text { digital como ferramenta } \\
\text { para desenvolver conteúdo. }\end{array}$ \\
\hline $\begin{array}{l}\text { Ciências da } \\
\text { Natureza }\end{array}$ & $\begin{array}{c}\text { Ciências da } \\
\text { Natureza }\end{array}$ & $\begin{array}{l}\text { Proposta de trabalhos } \\
\text { com vários gêneros } \\
\text { como meio, e não } \\
\text { como finalidade do } \\
\text { ensino }\end{array}$ & $\begin{array}{l}\text { Ilustrações e/ } \\
\text { ou modelos } \\
\text { digitais, } \\
\text { fluxogramas, } \\
\text { relatos } \\
\text { multimodais } \\
\text { etc. }\end{array}$ & $\begin{array}{l}\text { podem ser depreendidos } \\
\text { de ações gerais nas } \\
\text { unidades temáticas e para } \\
\text { o desenvolvimento de } \\
\text { habilidades específicas; } \\
\text { não são indicados de } \\
\text { forma direta. }\end{array}$ \\
\hline
\end{tabular}

Continua... 
Quadro 3-Continuação.

\begin{tabular}{|c|c|c|c|c|}
\hline Áreas & Componentes & $\begin{array}{c}\text { Gênero(s) } \\
\text { contemplado(s) } \\
\text { em intersecção } \\
\text { com o digital }\end{array}$ & Exemplos & $\begin{array}{c}\text { Percepção sobre } \\
\text { gêneros }\end{array}$ \\
\hline \multirow[b]{2}{*}{$\begin{array}{l}\text { Ciências } \\
\text { Humanas }\end{array}$} & Geografia & $\begin{array}{l}\text { Propõe o trabalho } \\
\text { com vários gêneros }\end{array}$ & $\begin{array}{l}\text { Gêneros } \\
\text { textuais, } \\
\text { mapas, } \\
\text { gráficos, } \\
\text { esquemas, } \\
\text { debates etc. }\end{array}$ & $\begin{array}{l}\text { considerados como } \\
\text { ferramenta ou suporte } \\
\text { dos gêneros propostos. }\end{array}$ \\
\hline & História & $\begin{array}{l}\text { Propõe o trabalho } \\
\text { com vários gêneros }\end{array}$ & $\begin{array}{l}\text { Narrativas } \\
\text { em diferentes } \\
\text { linguagens, } \\
\text { gráficos, } \\
\text { músicas, } \\
\text { documentos } \\
\text { iconográficos } \\
\text { etc. }\end{array}$ & $\begin{array}{l}\text { são depreendidos dos } \\
\text { trabalhos propostos nas } \\
\text { unidades que são diferentes } \\
\text { para cada ano, mas não } \\
\text { mencionam explicitamente } \\
\text { o meio digital. }\end{array}$ \\
\hline $\begin{array}{l}\text { Ensino } \\
\text { Religioso }\end{array}$ & Ensino Religioso & $\begin{array}{c}\text { Gêneros em } \\
\text { diferentes mídias }\end{array}$ & $\begin{array}{c}\text { Discussão, } \\
\text { matérias } \\
\text { midiáticas etc. }\end{array}$ & $\begin{array}{l}\text { aparecem como forma } \\
\text { de desenvolvimento das } \\
\text { habilidades específicas. }\end{array}$ \\
\hline
\end{tabular}

Fonte: Base Nacional Comum Curricular (Brasil, 2017).

Elaboração das autoras.

No Quadro 3, há gêneros contemplados na relação com tecnologias digitais - seja em qual de suas acepções for — em cada área/componente, indicando exemplos particulares e percepções. Com efeito, a frequência, o modo de apresentação (explícita ou implícita) e objetivo com que os gêneros discursivos são trazidos variam. Alguns componentes, como Língua Inglesa, apresentam muitos gêneros, de forma direta, e os têm como objetos de ensino; outros, como Ciências da Natureza e História, apresentam-nos indiretamente e em menor quantidade, porém, ao sugerirem ações para desenvolver seus conteúdos específicos, indicam a necessidade de análise e produção de gêneros para o desenvolvimento de habilidades desejadas.

Os dados reforçam a ideia de que na BNCC as orientações nem sempre recaem no trabalho específico com gêneros em relação ao digital, os quais podem ser depreendidos pela maneira com que são contextualizados nas práticas e ações para se abordar objetos de ensino ou mesmo para desenvolver habilidades específicas, ainda que certos componentes façam questão de marcar essa relação, trazendo gêneros digitais — ver Língua Portuguesa e Língua Inglesa - ou que necessitam de ferramentas digitais para serem desenvolvidos, como se nota na Educação Física. Portanto, a forma como as tecnologias digitais são vistas e suas variações recaem na abordagem de gêneros discursivos em cada área/componente, isto é, como instrumentos, para determinadas ações, como no caso da Matemática, ou como meios de produção, no caso dos gêneros digitais em Línguas Portuguesa e Inglesa (Linguagens).

A apresentação ou sugestão de trabalho com vários gêneros discursivos, em diferentes esferas nas áreas, é uma importante contribuição da BNCC e dá 
continuidade ao que estava proposto nos PCN (Rojo, 2000). Em contrapartida, é preciso cuidar da hipervalorização de gêneros da cultura digital, ainda que essa seja uma realidade à qual a escola não pode se furtar (Rojo, 2012, 2013), haja vista a multiplicidade de práticas sociais com tecnologias digitais, sobretudo de informação e de comunicação, de que os alunos e a sociedade participam.

É inegável a tentativa de a BNCC promover um trabalho com o digital em todas as áreas, explicitado desde sua "Introdução" e nas "Competências gerais". Assim, é necessária uma reflexão crítica sobre o efeito do documento no EFII e na formação docente, já que a BNCC engloba toda a educação básica do país, na qual o acesso tecnológico é desigual e as práticas de uso tecnológico também variadas.

A ênfase excessiva nos (novos) gêneros pode contradizer ainda a ideia de gênero discursivo que baseia o próprio documento, já que, como instiga Corrêa (2018, p. 120), o surgimento dos novos gêneros pode levar a "perde[re]m-se de vista as práticas sociais (as esferas de atividade humana) de que os gêneros provêm, destacando-se apenas sua vinculação com o ambiente tecnológico novo". O efeito cascata do documento desemboca nas salas de aula, o que não necessariamente significa que as práticas nelas desenvolvidas serão necessariamente eficazes como ele preconiza.

De outro modo, os desafios para a formação docente (inicial e continuada) são também reflexos da BNCC. Trabalhos, como de Miranda $(2016,2018)$ e Silva e Fuza (2017), demonstram lacunas na formação inicial de professores quanto ao tratamento efetivo de (novos) gêneros discursivos e tecnologias digitais e as dificuldades de atuação com gêneros, associados a tecnologias. Assim, outro resultado do efeito cascata da BNCC, inclusive conscientemente previsto, é modificar a formação de professores para preencher essa lacuna.

Nota-se que essa transformação diz respeito à familiaridade dos professores com tecnologias digitais, o que é ratificado por uma consulta à primeira versão da BNCC para a Formação de Professores (Brasil,2018). Nela, afirma-se a necessidade de formar professores aptos a "usar tecnologias apropriadas em suas práticas de ensino" (Brasil, 2018, p. 54) e "Selecionar tecnologias digitais, conteúdos virtuais e outros recursos tecnológicos que possam potencializar a aprendizagem" (Brasil, 2018 , p. 55). Novamente, é preciso ponderar que a tematização do digital, no nível superior ou em cursos de formação continuada, não será suficiente para a constituição desse professor esperado que domine e saiba promover um trabalho com tecnologias digitais. A própria versão inicial recomenda que se repense a ação dos formadores de professores: "A revisão da própria prática do docente de ensino superior formador do professor é imprescindível” (Brasil, 2018, p. 48).

Enfim, a BNCC mostra-se como desencadeadora de mudanças em vários níveis, como a sala de aula do EFII e a formação docente, principalmente nos cursos de licenciatura, o que poderá ser benéfico como promete, mas, ao mesmo tempo, gerar conflitos e descompassos sobre os quais precisamos discutir em espaços como este.

\section{CONSIDERAÇÕES FINAIS}

Analisar as concepções da BNCC sobre letramentos, tecnologias digitais e gêneros discursivos nas diferentes áreas do EFII propiciou-nos uma reflexão 
interdisciplinar que revelou pressupostos e possibilidades comuns para o desenvolvimento de cada componente curricular, como a visão ideológica de letramento, o entendimento diverso sobre o que sejam tecnologias digitais e o trabalho necessário com gêneros discursivos para o desenvolvimento das práticas de ensino.

Nosso estudo pôde demonstrar que a BNCC apresenta direções para práticas linguísticas em todas as áreas, pois a linguagem está subjacente às ações de ensino interdisciplinarmente. Compreendemos que as práticas de letramentos motivam o trabalho de todas as áreas e componentes, ainda que o conceito não seja apresentado textualmente por todas elas. Importante foi (re)conhecer a(s) concepção(ões) de letramento que as embasaram, para entender o que acarretavam para as propostas no desenvolvimento de conteúdos específicos, chamando-nos atenção à estreita relação com tecnologias digitais. Ademais, pudemos perceber uma difusão de noções sobre estas que impactavam diretamente no trabalho específico com gêneros discursivos possíveis para a sala de aula.

Além disso, destacamos desafios relativos à necessidade de criticidade sobre a aplicação direta e idealizada das orientações do documento nas práticas do EFII. Os caminhos analíticos percorridos, ao indicarem a diversidade de abordagens do digital proposta pela $\mathrm{BNCC}$, advertem que, apesar de divulgada como unificadora, ela não apresenta coesão em suas concepções, mesmo dentro de uma área/componente, dada a natureza situada dos conteúdos de ensino e sujeitos previstos no desenvolvimento de suas ações.

Diante disso, a heterogeneidade da sala de aula conflui para se refletir sobre o trabalho dos professores, cujas formações iniciais e continuadas se encontram em promessa de reestruturação, que não poderá ser realizada sem um questionamento da suposta homogeneidade esperada. O currículo, à luz da $\mathrm{BNCC}$, precisa ser fruto de discussões sobre fundamentos e objetivos de uma determinada formação, pois sem isso "a escolha dos conteúdos, saberes, práticas que passarão a compor um currículo se tornarão vazias, desarticuladas, reprodutoras de conflitos e de ideologias" (Girotto, 2017, p. 422).

Assim, o efeito cascata da BNCC sobre o ensino e a formação docente é um fato, porém seus reflexos reais serão percebidos em longo prazo. A nós, enquanto professores e formadores de professores, cabe contribuirmos com estudos, análises, conjecturas e críticas que fomentem sua implementação.

\section{REFERÊNCIAS}

BAKHTIN, M. Os gêneros do discurso. In: BAKHTIN, M. Estética da criação verbal. Tradução Paulo Bezerra. 4. ed. São Paulo: Martins Fontes, 2003 [1953]. p. 261-306.

BARTON, D.; HAMILTON, M. Local literacies: reading and writing in one community. London: Routledge, 2012.

BRASIL. Parâmetros Curriculares Nacionais: ensino fundamental. Brasília, DF: MEC/SEF, 1998.

BRASIL. Base Nacional Comum Curricular: educação é a base. (Versão dezembro 2017). Brasília, DF: MEC, 2017.

BRASIL. Proposta para Base Nacional Comum da formação de professores da educação básica. Versão Preliminar. Brasília, DF: MEC, 2018. 
BUZATO, M. E. K. Letramentos digitais e formação de professores. São Paulo: Portal Educarede, 2006. Disponível em: https://www.academia.edu/1540437/Letramentos_ Digitais_e_Forma\%C3\%A7\%C3\%A3o_de_P rofessores. Acesso em: 22 nov. 2009.

BUZATO, M. E. K. Cultura digital e apropriação ascendente: apontamentos para uma educação 2.0. Educação em Revista, Belo Horizonte, v. 26, n. 3, p. 283-303, 2010. Disponível em: http://www.scielo.br/scielo.php?script=sci_arttext\&pid=S010246982010000300014\&lng=en\&nrm=iso. ISSN 0102-4698. Acesso em: 13 jan. 2020. http://dx.doi.org/10.1590/S0102-46982010000300014.

CELLARD, A. A análise documental.. In: POUPART, J.; DESLAURIERS, J. P.; GROULX,L.H.; LAPERRIÈRE, A.; MAYER, R.; PIRES,A.P.A pesquisa qualitativa: enfoques epistemológicos e metodológicos. Petrópolis: Vozes, 2008. p. 295-316.

CORREA, M. L. G. Notas sobre letramentos, gêneros do discurso e (novas) práticas de leitura e escrita na internet. In: ABREU-TARDELLI, L. S.; KOMESU, F. Letramentos e gêneros textuais/discursivos: aproximações e distanciamentos. Belo Horizonte: Editora PUC-MINAS, 2018. p. 108-125.

CORREIA, A. P.; DIAS, P. A evolução dos paradigmas à luz das teorias curriculares. Revista Portuguesa de Educação, Braga, v. 11, n. 1, p. 113-122, 1998. Disponível em: https://core.ac.uk/download/pdf/55602184.pdf. Acesso em: 7 ago. 2019.

FONSECA, M.C.F. R. A educação matemática e a ampliação das demandas de leitura escrita da população brasileira. In: FONSECA, M. C. F. R. (org.). Letramento no Brasil: habilidades matemáticas. São Paulo: Global, 2004. p. 11-28.

FUZA, A. F. A constituição dos discursos escritos em práticas de letramento acadêmico-científicas. 2015. 368f. Tese (Doutorado em Linguística Aplicada) Universidade Estadual de Campinas, Campinas, 2015.

GERALDI, W. O ensino de língua portuguesa e a Base Nacional Comum Curricular. Revista Retratos da Escola, Brasília, v. 9, n. 17, p. 381-396, out./dez. 2015. http://dx.doi.org/10.22420/rde.v9i17.587

GIROTTO,E.D.Dos PCNs a BNCC: o ensino de geografia sob o domínio neoliberal. Geo UERJ, Rio de Janeiro, n.30, p.419-439,2017. https://doi.org/10.12957/geouerj.2017.23781 HOLDBROOK, J.; RANNIKMAE, M. The Meaning of Scientific Literacy. International Journal of Environmental \& Science Education, United Kingdom, v. 4, n. 3, p. 275-288, 2009.

KLEIMAN, A. Modelos de letramento e as práticas de alfabetização na escola. In: KLEIMAN, A. (org.). Os significados do letramento: uma nova perspectiva sobre a prática social da escrita. Campinas: Mercado de Letras, 1995. p. 15-61.

KLEIMAN,A.; DE GRANDE, P. B. Interseções entre a linguística aplicada e os estudos de letramento: desenhos transdisciplinares, éticos e críticos de pesquisa. Matraga Revista do Programa de Pós-Graduação em Letras da UERJ, Rio de Janeiro, v. 22, n. 36, jul. 2015. Disponível em: https://www.e-publicacoes.uerj.br/index.php/matraga/article/ view/17045. Acesso em: 28 dez. 2018. https://doi.org/10.12957/matraga

LÉVY, P. Cibercultura. São Paulo: Editora 34, 1999.

LÜDKE, M.; ANDRÉ, M. E. D. A. Pesquisa em educação: abordagens qualitativas. São Paulo: EPU, 1986. 
MARSIGLIA, A. C. G. A.; PINA, L. D.; MACHADO, V. O.; LIMA, M. Base Nacional Comum Curricular: um novo episódio de esvaziamento da escola no Brasil. Germinal: Marxismo e Educação em Debate, Salvador, v. 9, n. 1, p. 107-121, abr. 2017. http://dx.doi.org/10.9771/gmed.v9i1.21835

MIRANDA, F. D. S. M. Letramentos (en)formados por relações dialógicas na universidade: ressignificações e refrações. 2015. Tese (Doutorado em Linguística Aplicada) - Universidade Estadual de Campinas, Campinas, 2016.

MIRANDA, F. D. S. M. Questões sobre multimodalidade em materiais didáticos elaborados por professores em formação. In: APARÍCIO, A. S. M.; SILVA, R. S. (orgs.) Gêneros textuais: mediadores no ensino e aprendizagem de línguas. Campinas: Pontes, 2018. p. 129-154.

ONU — Organização das Nações Unidas. Agenda 2030. New York: ONU Brasil, 2015. Disponível em: http://www.agenda2030.org.br/. Acesso em: 13 jan. 2020.

ORRÚ, S. Base Nacional Comum Curricular: à contramão dos espaços de aprendizagem inovadores e inclusivos. Revista Tempos e Espaços em Educação, São Cristóvão, Sergipe, v. 11, n. 25, p. 139-152, abr./jun. 2018. https://doi.org/10.20952/revtee. v11i25.6828

ROCHA, N. F.E.; PEREIRA, M.Z.C. O que dizem sobre a BNCC? Produções sobre a Base Nacional Comum Curricular (BNCC) no período de 2010 a 2015. Espaço do Currículo, v. 9, n. 2, p. 215-236, 2016. https://doi.org/10.15687/rec.v9i2.29922

ROJO, R.H. R. (org.). A prática de linguagem em sala de aula: praticando os PCNs. São Paulo: EDUC; Campinas: Mercado de Letras, 2000.

ROJO, R.H. R. Pedagogia dos multiletramentos: diversidade cultural e de linguagens na escola. In: ROJO, R. H. R.; MOURA, E. (orgs.). Multiletramentos na escola. São Paulo: Parábola editorial, 2012. p. 11-31.

ROJO, R. H. R. (org.). Escola conectada, os multiletramentos e as TICs. São Paulo: Parábola, 2013.

ROJO, R. H. R. Entre plataformas, ODAs e protótipos: novos multiletramentos em tempos de WEB2. The ESPecialist, [S.l.], v. 38, n. 1, jul. 2017. https://doi. org/10.23925/2318-7115.2017v38i1a2

ROJO, R. H. R.; BARBOSA, J. P. Hipermodernidade, multiletramentos e gêneros discursivos. São Paulo: Parábola Editorial, 2015.

ROJO, R. H. R. Pedagogia dos multiletramentos: diversidade cultural e de linguagens na escola.In: ROJO, R.H. R.; MOURA, E. (Org.). Multiletramentos na escola. São Paulo: Parábola editorial, 2012, p. 11-31.

SANTOS, M. J. C.; MATOS, F. C. C.; SILVA, W. H.; SANTOS, V. C. O letramento matemático e o conceito de número: algumas reflexões. In: CONGRESSO NACIONAL DE EDUCAÇÃO, 4., 2017, João Pessoa. Anais [...]. João Pessoa: CONEDU, 15 a 18 nov. 2017.

SAVIANI, D. Educação escolar, currículo e sociedade: o problema da Base Nacional Comum Curricular. Movimento Revista de Educação, Rio de Janeiro, n. 4, p. 54- 85, 2016. https://doi.org/10.22409/mov.v0i4.296 
SILVA, I. C. S.; FUZA, Â. F. Tecnologias digitais na formação de professores em Letras. Trem de Letras, Alfenas, v. 3, n. 1, p. 137-161, 2017.

SILVA, W. R. et al. Ciência nas licenciaturas? Linguagem - Estudos e Pesquisa, Catalão, v. 22, n. 1, p. 83-108, jan./jun. 2018. https://doi.org/10.5216/lep.v22i1.54461 SILVA, W. R. et al. Letramento científico na formação inicial do professor. Práticas de Linguagem, Juiz de Fora, v. 6, n. especial, p. 8-23, 2016.

SOARES, M. O que é letramento e alfabetização. In: SOARES, M. (org.). Letramento: um tema em três gêneros. 2. ed. Belo Horizonte: Autêntica, 2006. p. 27-60.

STREET, B. Literacy in theory and practice. Cambridge: Cambridge University Press, 1984.

STREET, B. What's "new" in new literacy studies? Critical approaches to literacy in theory and practice. Current Issues in Comparative Education, London, v. 5, n. 2, p. 77-91, 2003.

SZUNDY, P.T. C. A Base Nacional Comum Curricular: implicações para a formação de professores/as de língua(gens). In: MATEUS, E.;TONELI,J. R. A. (orgs.). Diálogos (im)pertinentes entre formação de professores e aprendizagem de línguas. São Paulo: Blucher, 2017. p. 77-98.

TREVISAN, R. BNCC: o que é o raciocínio geográfico e como desenvolvê-lo com seus alunos. Nova Escola, São Paulo, s/d. Disponível em: https://novaescola.org.br/bncc/ conteudo/79/o-que-e-o-raciocinio-geografico-e-como-desenvolve-lo-com-seus-alunos. Acesso em: 30 dez. 2018.

VALSECHI, M. C.; KLEIMAN, A. B. O estágio supervisionado e a voz social do estagiário. Raído, Dourados, v. 8, n. 15, jan./jun. 2014.

\section{SOBRE AS AUTORAS}

Ângela Francine Fuza é doutora em linguística aplicada pela Universidade Estadual de Campinas (UNICAMP). Professora da Universidade Federal do Tocantins (UFT).

E-mail: angelafuza@uft.edu.br

Flávia Danielle Sordi Silva Miranda é doutora em linguística aplicada pela Universidade Estadual de Campinas (UNICAMP). Professora da Universidade Federal de Uberlândia (UFU).

E-mail: flaviasordi@gmail.com

Recebido em 14 de janeiro de 2019

Aprovado em 16 de setembro de 2019 